ISSN 1112-9867

\title{
EFFICIENCY OF WASTEWATER TREATMENT BY A MIXTURE OF SLUDGE AND MICROALGAE
}

H. Khaldi ${ }^{1}$, M. Maatoug ${ }^{1, *}$, C. S. Dube ${ }^{2}$, M. Ncube ${ }^{2}$, R. Tandlich ${ }^{2}$, H. Heilmeier ${ }^{3}$, R. K. Laubscher $^{4}$, A. Dellal ${ }^{1}$

${ }^{1}$ L. A.B.N.S.A., Faculty of Natural and Life Sciences, University of Tiaret, Algeria

${ }^{2}$ Environmental Health and Biotechnology Research Group, Division of Pharmaceutical Chemistry, Faculty of Pharmacy, Rhodes University, Grahamstown 6140, South Africa, ${ }^{3}$ AG Biologie/Ökologie, InstitutfürBiowissenschaften TU Bergakademie Freiberg Leipziger Str. 29, D-09599 Freiberg, Germany

${ }^{4}$ EBRU, Rhodes University, P.O. Box 94, Grahamstown 6140, South Africa

Received: 27 April 2017 / Accepted: 15 July 2017 / Published online: 01 September 2017

\begin{abstract}
A combined system using the microalgae from South Africa and the sewage sludge from Algeria has been tested, in order to study the efficiency of wastewater treatment by mixtures of microalgae / activated sludge, five bioreactors were installed with different inoculation rates (microalgae / activated sludge) B1: 100\% algae, B2: 90.90\%: 9.1\%, B3: 83.33\%: 16.67\%, B4: 50\%: 50\% and B5: 16.67: 83.33. The best removal percentages were measured as: $76.36 \%$ for $\mathrm{PO}_{4}-\mathrm{P}, 94.90 \%$ for $\mathrm{NO}_{3}-\mathrm{N}, 90.42 \%$ for $\mathrm{NH}_{4}-\mathrm{N}$ and $65.73 \%$ for $\mathrm{COD}$, in the combined system. Except in the case of COD, there were highly significant effects of different inoculations rates on yield. The best results are those of the bioreactor B5. These results suggest that the nutrients in the wastewater can be effectively eliminated by co-cultivation of micro-algae with bacteria (activated sludge).
\end{abstract}

Keywords: Wastewater; phosphates; nitrates; ammonium; COD; microalgae / activated sludge; bioreactor.

Author Correspondence, e-mail: maatoug.moh@gmail.com

doi: http://dx.doi.org/10.4314/jfas.v9i3.13 


\section{INTRODUCTION}

Algeria is located on the Mediterranean coast of the continent, while South Africa is a country located on the southern tip of Africa. Both are classified as water-scarce countries [1]. Urbanisation and other factors have resulted in dramatic increases in volumes of industrial effluents and domestic sewage which require treatment in the wastewater treatment facilities in Algeria [2]. Water provision and related infrastructure have undergone significant improvements in last couple of decades in the country. However, despite the achieved success only about $20 \%$ of the total volumes of the produced wastewater have been reported to be effectively treated in Algeria [3].

The search for adequate treatment means and reuse of sewage effluent has become an attractive option and an essential alternative to mobilize large volumes of water and thus to satisfy the increasingly growing demand for water, especially in arid and semi-arid countries, as well to protect human health and environment. [4]

Among many systems applied and used nowadays, activated sludge treatment plants are the most popular and frequently used for wastewater treatment worldwide [5]. However, this technique involves major disadvantages such as: relatively high investment costs and high energy demands. In this technique the removal of nitrogen and phosphorus including sludge treatment, denitrification pond and chemical precipitation of phosphorus generate a great volume of sludge waste that must be transported off-site for disposal, release nitrogen to the atmosphere and use additive chemicals [6,7].

Microalgae have attracted considerable attention in recent years for improving water quality and treating wastewater in an environmentally friendly way [8,9]. Many studies have shown that algae offer the advantage of having high growth rates and being capable of assimilating nitrogen and phosphorus from wastewater with low operational costs, no secondary pollution, efficient recycling of nitrogen and phosphorus, no requirement of organic carbon and no $\mathrm{CO}_{2}$ emission, generation of microalgal biomass which can be used for feedstock, fertilizer, biofuel, for which, it is widely used [4,10-15].

Microalgae have been used successfully for the treatment of sewage and domestic wastewater $[16,17]$, as they have already been used in the secondary effluent treatment, agriculture, pigsty 
and dairy effluent [4,18-19]. They also provide an alternative and highly effective method for biosorption of heavy metals found in water as : $\mathrm{Pb}, \mathrm{Cu}, \mathrm{Cr}$ and $\mathrm{Zn}$ [20-22].

Biotechnology based microalgae-bacteria communities are of great interest as an alternative method of conventional treatment process of wastewater, especially in sunny areas, because of their photosynthetic capacity. This is of particular relevance in Algeria and South Africa, which have favorable solar radiation conditions for the implementation of the microalgae-sludge system in wastewater treatment. The annual energy available from solar radiation in Algeria has been reported to range from 1700 to $2263 \mathrm{~kW} \mathrm{~h} / \mathrm{m}^{2} /$ year [23]. The algae produce oxygen which can be used by aerobic bacteria to biodegrade organic matter, while in return they consume carbon dioxide released by bacterial respiration which provides a cheaper and safer alternative to the mechanical ventilation and contributes to reduction of $\mathrm{CO}_{2}$ emissions [24]. In the algae-bacteria system, microalgae played a dominant role in the removal of nitrogen and phosphorus, while bacteria removed most of the organic matter from the wastewater [25]. Initial reports between algae and bacteria can influence the relationship of cooperation and lead to different treatment effectiveness [26]. Symbiotic microalgal-bacterial biofilms can be very attractive for municipal wastewater treatment [27], the microalgal-bacterial symbiosis has been studied in ponds and tubular photo-bioreactors. De Godos et al. [28] used a tubular biofilm-based photo-bioreactor to treat pretreated swine slurry, and found that the microalgal-bacterial symbiosis could achieve nitrogen $(\mathrm{N})$, phosphorus (P) and chemical oxygen demand (COD) removal efficiencies up to $100 \%, 90 \%$ and 75\%, respectively with no external $\mathrm{O}_{2}$ supply. Ma et al. [29] demonstrated a mutual compound relationship between algae and wastewater-borne bacteria. Algae can promote bacterial growth and optimal initial algal concentration may be more favorable for bacterial growth. Liang et al [30] prove that nutrients in wastewater can be removed efficiently by the algae-bacteria combined system the results showed that $78 \%$ of $\mathrm{NH}_{4}$ could be removed in the combined system, while $29 \%$ in single algae system and only $1 \%$ in single bacteria system. Approximately $92 \%$ of Total Phosphate was removed in the combined system, compared with $55 \%$ and $78 \%$ in single algae and bacteria system. In this symbiotic relationship the microalgae release $\mathrm{O}_{2}$ which is consumed as electron acceptor by the heterotrophic bacteria. 
In turn, the bacteria release carbon dioxide $\left(\mathrm{CO}_{2}\right)$ which is taken up by the microalgae for cell growth.

Collaboration has been initiated between the University of Ibn Khaldoun in Tiaret, Algeria and Rhodes University in Grahamstown, South Africa on the reuse of sewage sludge produced in the wastewater treatment facilities in both cities. Preliminary results of this collaboration indicated that the sewage sludge from the wastewater treatment plant Grahamstown is not stabilised enough for reuse, while, the sewage sludge from the wastewater treatment plant in Tiaret, Algeria is stabilised enough to allow for reuse [31]. The algal pond system is present here and has been studied extensively [32]. The algal system present in Grahamstown and the sludge from Tiaret were used as the basis for the development of a typical microalgal-sludge treatment system for wastewater treatment.

The objective of this work is to study the effect of different ratios of inoculation between micro-algae and activated sludge treatment of sewage and the evolution of some parameters, such as phosphate, nitrate, ammonium and the chemical oxygen demand, depending on the removal kinetics and dose used, in order to define the best value for performance.

\section{EQUIPEMENT AND METHODS}

\subsection{Characteristics of microalgae used in bioreactors}

Microalgae used in this study are from the High Rate Algae Pond (HRAP) which is part of Integrated algae pond system (IAPS) for wastewater treatment constructed at the Rhodes University Environmental Biotechnology Experimental Field Station, Grahamstown, reveals a diversity of micro flora and fauna (fig.1) [33]. 


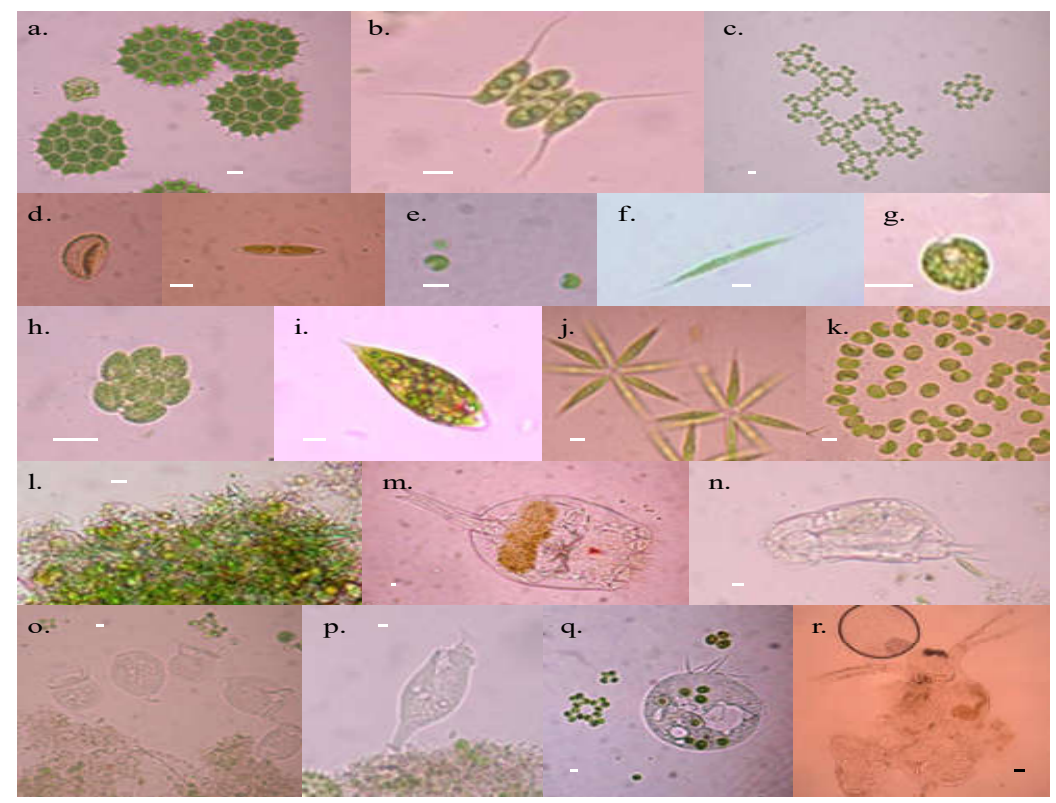

Fig.1. Microflora and fauna present in water samples from High Rate Algae Oxidation Ponds treating domestic waste water. Microalgae: a.Pediastrum,b. Scenedesmus, c.Micractinium,d.

Diatoms, e. Chlorella, f.Closterium, g.Chlamydomonas, h.Pyrobotrys,i. Euglena, j.Actinastrum,k.Dictyosphaerium, l. Blue greens. Zooplankton: m.Brachionus, n.Lecane, o.Conochilus, p.Philodina,q.Cyclidium, r.Daphnia. White scale bar is $5 \mu \mathrm{m}$ (for microalgae and rotifers) and black scale bar is $50 \mu \mathrm{m}$ (for Daphnia).

\subsection{Characteristics of the sludge used in bioreactors}

The physicochemical characteristics of the sludge are shown in Table 1. The concentrations of $\mathrm{NO}_{3}{ }^{-} \mathrm{N}, \mathrm{PO}_{4}^{-3}-\mathrm{P}$ and $\mathrm{NH}_{4}{ }^{+}-\mathrm{N}$ were determined as mentioned in the Analytical Methods section. Enumerations of Escherichia coli (designated as E. coli) as colony-forming units per $100 \mathrm{~mL}(\mathrm{CFUs} / 100 \mathrm{~mL})$ in all samples was performed using the membrane filtration technique on the Hi-Chrome m-TEC agar (Sigma-Aldrich) [34]. The membrane filters used were the sterile Pall-Gelman GN-6 Metricel membrane filters (pore size $0.45 \mu \mathrm{m}$, diameter $47 \mathrm{~mm}$ ). The presence of heterotrophic bacteria (HPC) in the sludge was determined using the spread-plate method on the R2A agar (Sigma-Aldrich). Dilutions were done in sterile physiological saline [35]. Incubations for HPC enumerations were performed at $35{ }^{\circ} \mathrm{C}$ for 48 hours. $\mathrm{pH}$ and Electrical conductivity (EC) were measured using a $\mathrm{pH}$ meter and conductimeter (HANNA) respectively. 
Table 1.Characteristics of sludge used in the experiment.

\begin{tabular}{ll}
\hline Physico-chemical and bacteriological parameters & Values \\
\hline Electrical conductivity EC (mS/cm) & $4.7 \pm 0.1$ \\
Nitrate (mg/g.d.w) & 2.6 \\
Phosphate( mg/g.d.w) & 0.2 \\
Ammonium ( mg/g.d.w) & 0.6 \\
Organic Matter (\%) & $44.8 \pm 16$ \\
pH & $8.04 \pm 0.20$ \\
Concentration of bacteria E. Coli CFU/g d.w. & $7769 \pm 1268$ \\
Concentration of heterotrophic bacteria CFU/g d.w. & $1.43 \times 10^{9} \pm 9.11 \times 10^{8}$ \\
\hline
\end{tabular}

\subsection{Preparation of bioreactors}

Wastewater treatment tests were performed in five photo-bioreactors, which were made of transparent glass with a volume capacity of 15 liters, at room temperature (about $23{ }^{\circ} \mathrm{C}$ ). The total volume of liquid in the bioreactor is 14 liters (approx. $25 \mathrm{~cm}$ in depth). The microalgae inoculum was collected from the Integrated Algal Pond System (IAPS) located at the Institute for Environmental Biotechnology at Rhodes University (EBRU). The operational characteristics of the IAPS have been described before [32]. The microalgae sludge systems were set up using an approach similar to that of [36]. The collected microalgae inoculum was firstly settled down for $3 \mathrm{~h}$, then the settled solids were used as microalgae inoculums. The aerobic activated sludge obtained from the wastewater treatment plant of Tiaret- Algeria, was used as bacteria inoculum. The total suspended solid (TSS) of initial microalgae inoculums and of initial activated sludge inoculums was $8 \mathrm{~g} / \mathrm{l}$. The five bioreactors were filled with1200, 1090.9, 1000, 600 and $200 \mathrm{ml}$ algae inoculums and 0, 109.1, 200, 600 and $1000 \mathrm{ml}$ activated sludge inoculums to obtain the following algae/sludge ratios respectively: $100 \%$ algae (bioreactor B1), 90.90\% / 9.10\% (bioreactor B2) ; 83.33\% / 16.67\% (bioreactor B3) ; 50\% / $50 \%$ (bioreactor B4) et $16.67 \%$ / 83.33\% (bioreactor B5). The total inoculums volume finally obtained in bioreactor was 1.2 liter. The total volume of each bioreactor's content was made to 14 liters with addition of 12.8 liters of wastewater. The characterization of wastewater was: 
COD: $1417.80 \pm 13.11 \mathrm{mg} \mathrm{O} / 1, \mathrm{NH}_{4}-\mathrm{N}: 134.13 \pm 0.48 \mathrm{mg} / 1, \mathrm{PO}_{4}-\mathrm{P}: 5.49 \pm 0.02 \mathrm{mg} / 1, \mathrm{NO}_{3}-\mathrm{N}$ : 196.09 $\pm 4.1 \mathrm{mg} / \mathrm{l}$. Constant agitation was maintained using air pump to avoid algae sedimentation. All bioreactors were illuminated with two SQI LED T8 tube green technology lamps, with a $12 \mathrm{~h}$ light- $12 \mathrm{~h}$ dark cycle. The experiments were run at light intensity about 380 lx (measured at the top of the liquid surface using the LX101 LUX light meter. Samples of the treated wastewater were removed from the bioreactors every 24 hours for 12 days.

\subsection{Analytical methods}

Kits used for the chemical analysis of wastewater and sludge were purchased from Merck Pty. Ltd. Chemical analysis were performed as reported by [37]. Spectrophotometric measurements were performed using the SHIMADZU 1240 UV/VIS Spectrophotometer. In each bioreactor, the following chemical parameters were measured: the Chemical Oxygen Demand (COD), concentrations of ammonium $\mathrm{NH}_{4}{ }^{+}-\mathrm{N}$, nitrate $\mathrm{NO}_{3}{ }^{-}-\mathrm{N}$ and phosphate $\mathrm{PO}_{4}{ }^{3}-\mathrm{P}$. The samples were filtered by Whatman filters $(0.45 \mu \mathrm{m})$. All weights were determined using the Pionner ${ }^{\mathrm{TM}}$ PA214 analytical balance or PA2102 balance. The pH of all samples was measured using Crimson pH-meter), calibrated at $\mathrm{pH} 4.0, \mathrm{pH} 7.0$ and $\mathrm{pH} 10$ using standard buffers.

\subsection{Statistical Analysis}

The statistical treatment was performed, using the software package: STATISTICA version.12 Factorial Anova was used to study the effect of the purification time, bioreactor and interaction bioreactor- purification time on the various parameters measured. A $p$ value of less than 0.05 was considered as statistically significant.

\section{RESULTS AND DISCUSSION}

\subsection{Effect of the micro-algae / activated sludge mixture on different parameters}

In the objective to study the evolution of yields and the contents: $\mathrm{PO}_{4}-\mathrm{P}, \mathrm{NH}_{4}-\mathrm{N}, \mathrm{NO}_{3}-\mathrm{N}$ and COD, in the bioreactors with different inoculation rates. The percentages of calculated yields are shown in Fig 2 for all parameters measured in the bioreactors. The detailed results obtained and the discussion are treated on a case-by-case basis, taking into account the 
factorial Anova test and the correlation parameter - purification time (from fig 3 to fig 6).
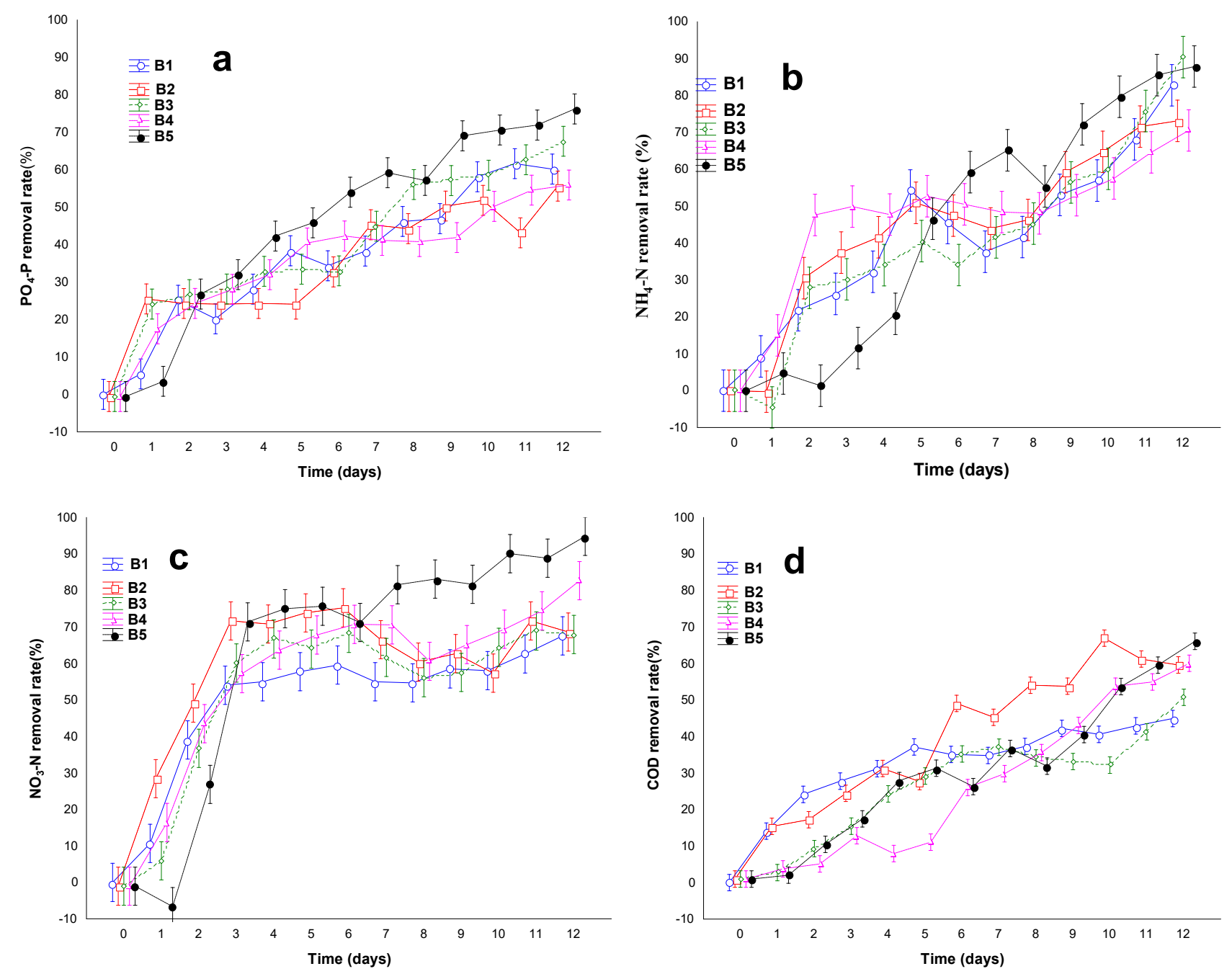

Fig.2. Removal efficiencies of $\mathrm{PO}_{4}-\mathrm{P}, \mathrm{NH}_{4}-\mathrm{N}, \mathrm{NO}_{3}-\mathrm{N}$ and $\mathrm{COD}$ in the bioreactors during the operation time.

\section{a) Effect on the Phosphates $\mathrm{PO}_{4}-\mathrm{P}$}

The concentration evolution of $\mathrm{PO}_{4}-\mathrm{P}$ in the five bioreactors is shown in the fig. 3. Phosphate contents are negatively correlated with purification time, in all bioreactors. Phosphates contents were reduced from $5.49 \pm 0.02 \mathrm{mg} / \mathrm{l}$, in initial state, to $1.29 \pm 0.02 \mathrm{mg} / \mathrm{l}$, in the 12 th day, with a yield of $76.36 \%$ in the bioreactor 5 , against $60.39 \%$ in the bioreactor 1 containing only algae $\left(r=-0.94^{* * *}\right)$. Nevertheless, the bioreactors 2,3 and 4 have yields of: $55.87 \%, 67.77 \%$ and $56.15 \%$ respectively (fig. $2 \mathrm{a}$ ) and $\mathrm{r}=-0.98 * * *, \mathrm{r}=-0.94 * * *$ and $\mathrm{r}=-0.93 * * *$ respectively. Su et al. [36] have found a low removal yield in the bioreactor which contains only the algae 
yield of $54.4 \%$, for reason of low efficiency of phosphorus removal in the bioreactor; this is due to the inhibition of light between algal cells, which led to low growth of autotrophic algae. As, the only source of $\mathrm{CO}_{2}$ is the air and in absence of the main partner of the supply of $\mathrm{CO}_{2}$ (sludge), the photosynthesis of algae, may be co-limited by $\mathrm{CO}_{2}$ as well. Heterotrophic bacteria have the ability to decompose the organic phosphorus [38], what explains the high yield in the bioreactor 5. Liao et Dawson [39] and Uba et al. [40] showed that the wastewater is rich in microorganisms such as Acinetobacter, Alcaligenes, Flavobacterieum and Psodomonas predominate. Fuhs et Chen [41] identified, the Acinetobacters as the bacterial genus mainly responsible for the reduction of phosphorus.

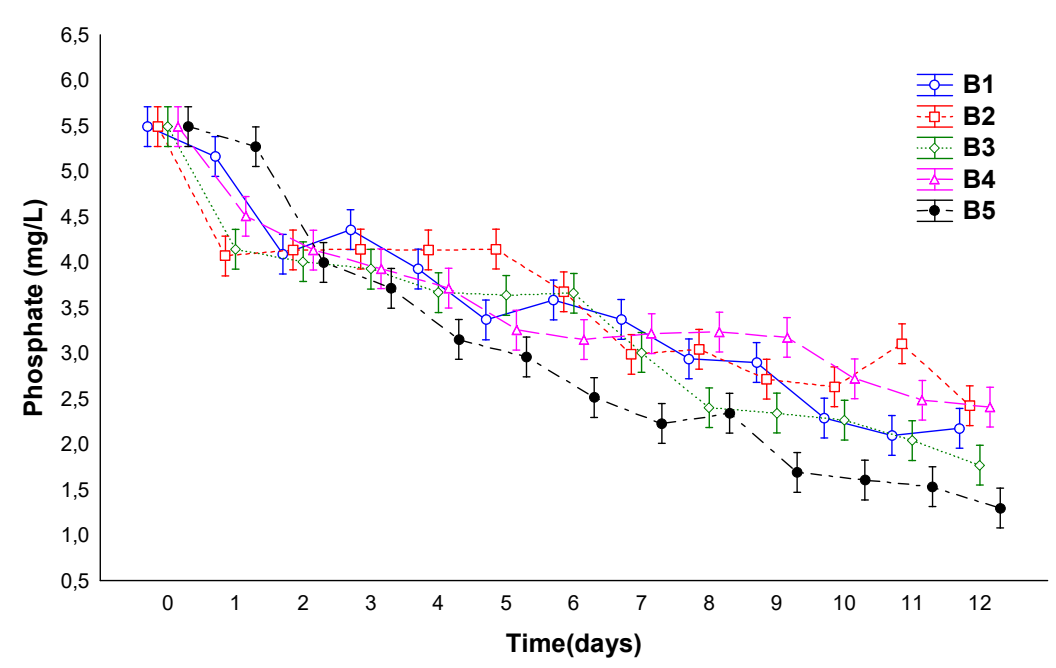

Fig.3. Evolution of $\mathrm{PO}_{4}-\mathrm{P}$ concentration in the bioreactors depending on purification time

\section{b) Effect on the Ammonium $\mathrm{NH}_{4}-\mathrm{N}$}

The variation of $\mathrm{NH}_{4}-\mathrm{N}$ concentration according to time in the five bioreactors is depicted in the fig.4. Significant correlations were also recorded between the purification time and the contents of Ammonium in the five bioreactors. We noted a decrease from 134.13 $\pm 0.48 \mathrm{mg} / \mathrm{l}$, in the effluent, to $12.84 \pm 1,18$ in the bioreactor $3(\mathrm{r}=-0.94 * * *)$ and $16.28 \pm 0.79 \mathrm{mg} / \mathrm{l}$ in the bioreactor $5\left(\mathrm{r}=-0.96^{* * *}\right)$, the last day, with best yields of $90.42 \%$ and $87.86 \%$ respectively. Important yields were also observed in bioreactors 1,2 and $4: 82.78 \% ; 73.13 \%$ and $70.54 \%$ (fig.2b) and $\left.\mathrm{r}=-092 * * *, \mathrm{r}=-0.88^{* * *}, \mathrm{r}=-0.97 * * *\right)$ respectively. These results were confirmed by $\mathrm{Su}$ et al. [36], who emphasized that the removal efficiency of $\mathrm{NH}_{4}-\mathrm{N}$ was about 
$99 \%$, for a mixture of algae - activated sludge (inoculation rate 5: 1), On the other hand, when they used the only algae or the only activated sludge; The yields are of the order of $52 \%$ and $14 \%$ respectively. This indicates that the removal of $\mathrm{NH}_{4}-\mathrm{N}$ can be increased by co-cultivation of algae with bacteria.

The best yield in the bioreactor 3 seems influenced by his proper inoculation rate which promoted cooperation between the algae and activated sludge, as was found by $\mathrm{Su}$ et al. [36].

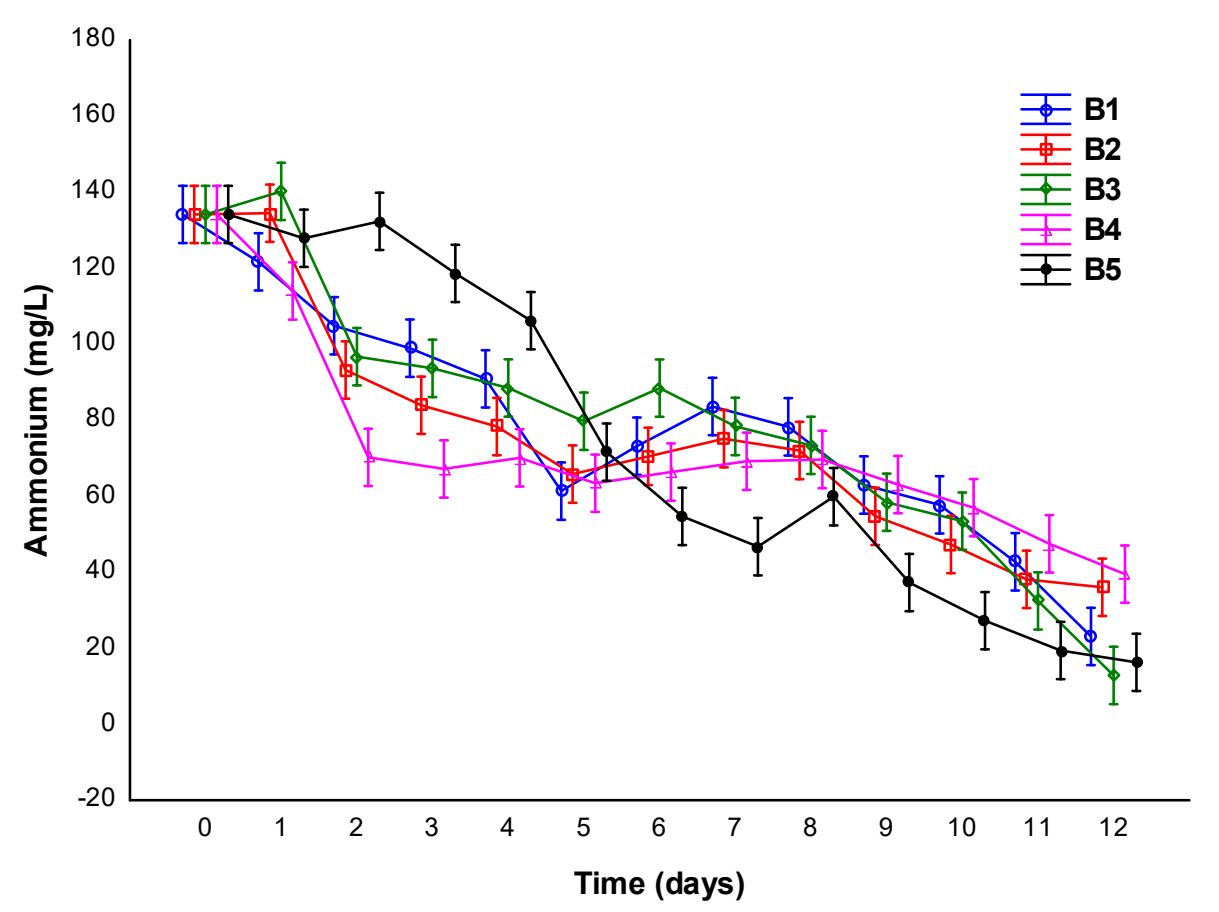

Fig.4. Evolution of $\mathrm{NH}_{4}-\mathrm{N}$ concentration with purification time in the bioreactors

\section{c) Effect on the Nitrates $\mathrm{NO}_{3}-\mathrm{N}$}

The fall in concentrations of nitrates in the five bioreactors, can certainly be explained by its use by microalgae (fig5). Significantly negative correlation was recorded. A decrease was highly remarkable from $196.09 \pm 4.01 \mathrm{mg} / \mathrm{l}$, in the effluent to $9.99 \pm 1.11 \mathrm{mg} / \mathrm{l}$ after 12 days, in the bioreactor 5 , a yield of $94.90 \%\left(\mathrm{r}=-0.83^{* * *}\right)$. Also an important yield is attributed to the bioreactor 4 , of the order of $82.85 \%(r=-0.80 * * *)$. For the bioreactors 2 and 3 , the recorded values are $68.93 \%$ and $68.26 \%$, and $\mathrm{r}=-0.58 * * *, \mathrm{r}=-0.72 * * *$ respectively. (fig. $2 \mathrm{c}$ ).

The decrease in the concentrations of nitrate being the result of the functioning of bacteria, such as for the abundant $\mathrm{NH}_{4}-\mathrm{N}$, which exists in the wastewater and which is removed by the 
latter [25]. The bacteria have also absorb nitrates $\mathrm{NO}_{3}-\mathrm{N}$ to foster individual growth when a sufficient organic matter is available, leading to a decrease of $\mathrm{NO}_{3}-\mathrm{N}$ in the initial phase, and gradually as the organic matter decreases, the metabolism of bacteria begins to slow down, because of the depletion of energy sources, where after the concentrations of nitrate have remained at a constant level [25] what we clearly see in Figure 5. Ruiz et al. [42] also find that the microalgae easily use the ammonium $\mathrm{NH}_{4}-\mathrm{N}$ when the two elements: $\mathrm{NH}_{4}-\mathrm{N}$ and $\mathrm{NO}_{3}-\mathrm{N}$ coexist both in the medium, because the enzymes necessary for the reduction of nitrates are deactivated by the ammonium assimilation process, whereas after removal of $\mathrm{NH}_{4}-\mathrm{N}$ in wastewater, microalgae start to use nitrates which causes a rapid decrease and final elimination of the latter.

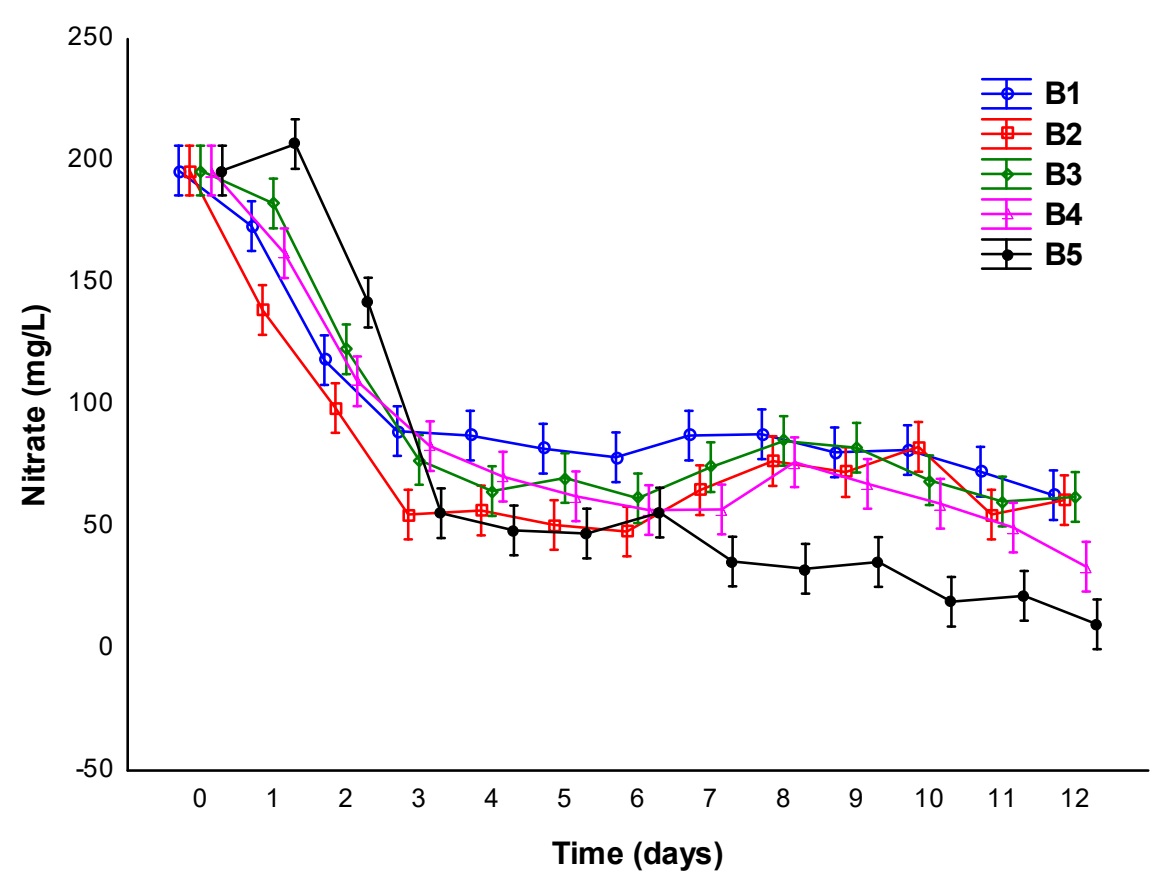

Fig.5. Evolution of $\mathrm{NO}_{3}-\mathrm{N}$ concentration in the bioreactors depending on time

\section{d) Effect on the chemical oxygen demand COD}

The COD represents the amount of oxygen consumed by the chemically oxidisable matter contained in water. It is representative of the majority of the oxidisable organic compounds. The changes in COD with time in the five bioreactors are shown in fig.6; the COD is negatively correlated with the treatment time, for all bioreactors. The best yield is recorded in the $\mathrm{B} 5$, the COD decrease from $1417.8 \pm 13.1 \mathrm{mg} \mathrm{O}_{2} / 1$, to $485.8 \pm 14.0 \mathrm{mg} \mathrm{O}_{2} / 1$, in the last day, 
removal yield $65.73 \%$, indicating the importance of cooperation between the algae and activated sludge $\left(\mathrm{r}=-0.96^{* * *}\right)$.

The lowest yield was obtained in the bioreactor 1 containing only algae. The COD decreased from $1417.8 \pm 13.1 \mathrm{mg} \mathrm{O}_{2} / 1$ in the effluent to $788.46 \pm 25.00 \mathrm{mg} \mathrm{O}_{2} / 1$ after 12 days, a yield of $44.38 \%\left(\mathrm{r}=-0.89^{* * *}\right)$. This low performance can be explained by the absence of sludge that improves the degradation of organic carbon, requiring a high content of oxygen to fill this process. Studies have indicated that the bacteria can decompose the organic complex on small molecules such as nutrients for use by algae [43]. The microalgae provided oxygen by photosynthesis to aerobic heterotrophic bacteria to mineralize the organic pollutants [44].

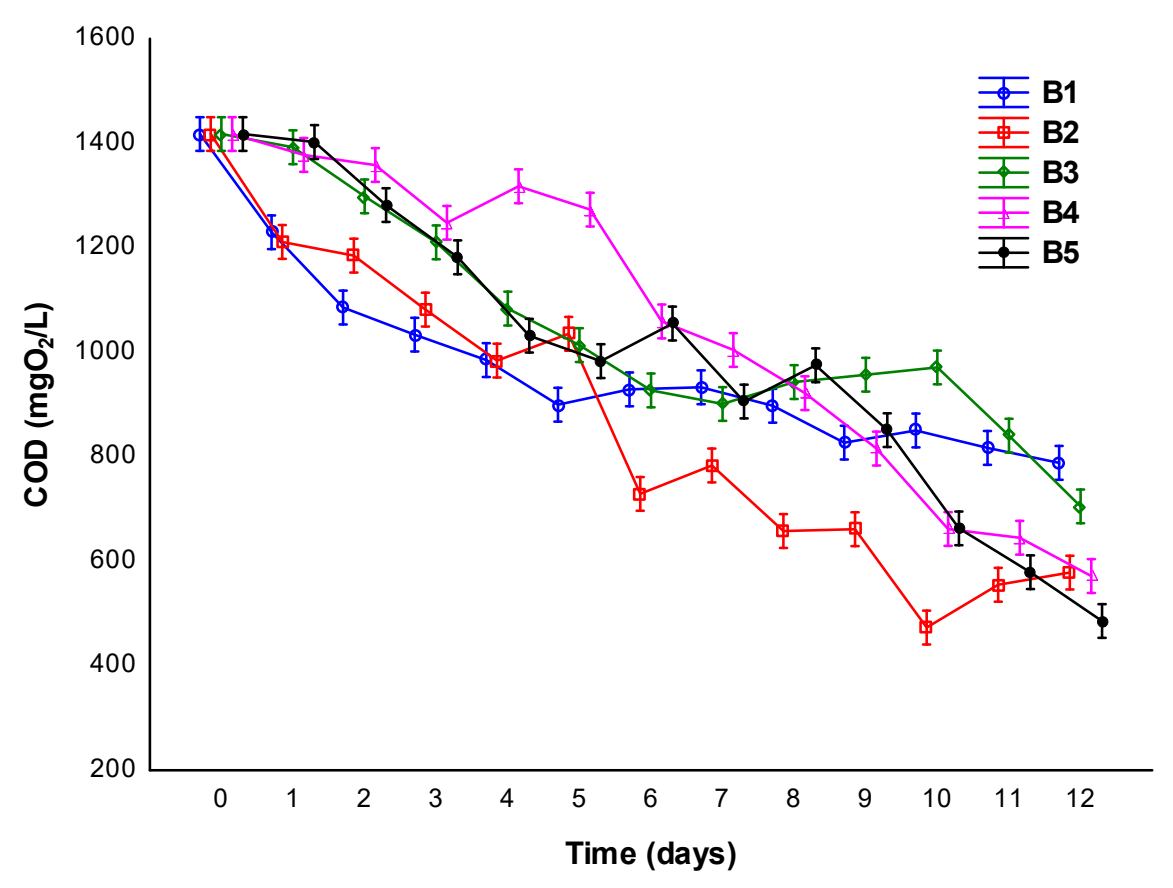

Fig.6. Evolution of COD concentration in the bioreactors depending on time

\subsection{Interaction bioreactor- purification time}

In fig.7, We note a very highly significant test for the interaction bioreactor - purification time. $(p=0.000)$. Ammonium, COD, Nitrate and Phosphate levels are higher in the first day of sampling. They reached low values on the 12th day. The degradation of these parameters appears to be important in the bioreactor 5 where the purifying efficiency is high. 


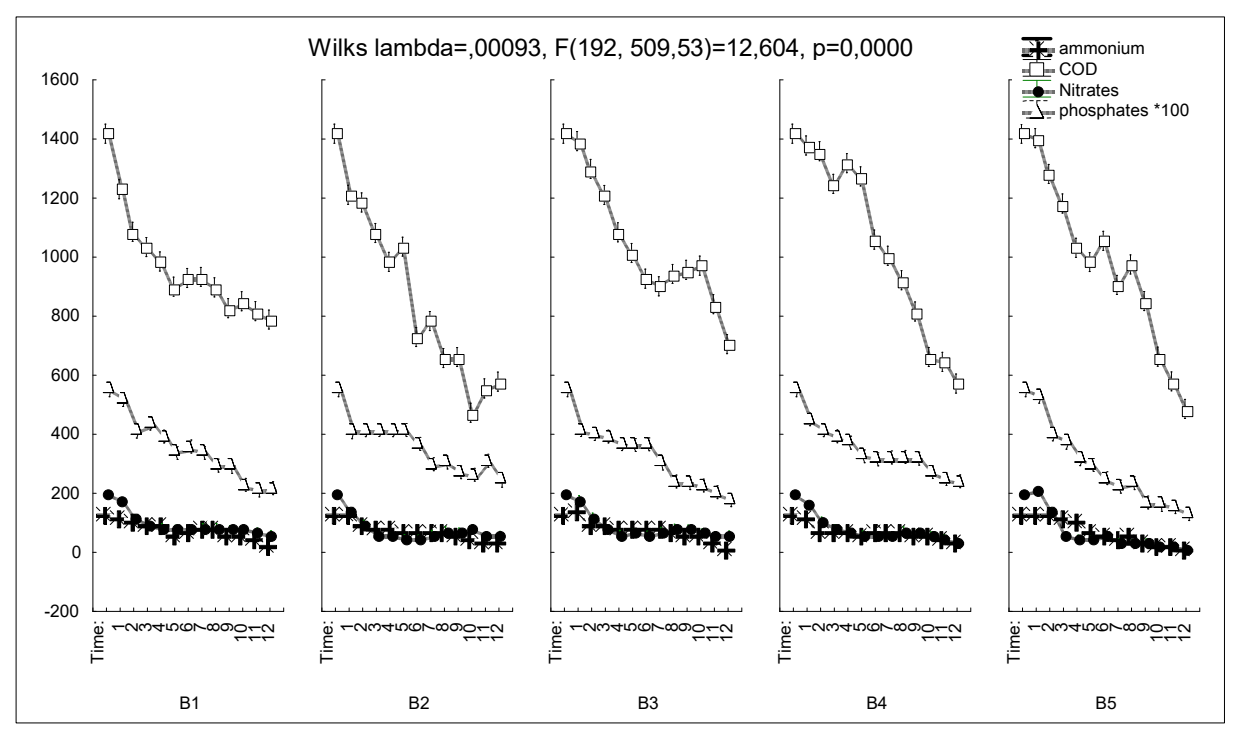

Fig.7. Effect of purification time, bioreactor and time-bioreactor interaction on different parameters

\subsection{Evolution of $\mathrm{pH}$ according to the purification time in the five bioreactors}

Change in $\mathrm{pH}$ of the bioreactors inoculated with different algae/activated sludge ratios are shown in Fig. 8. The role of the $\mathrm{pH}$ is a decisive factor for the growth of microorganisms in an aquatic medium; the growth of most of the microorganisms that live there is affected by acid $\mathrm{pH}$. The figure 8 shows an acid trend recorded during the first days for all the bioreactors.

Is that only from the 5th day that $\mathrm{pH}$ values tend to increase? Indeed, the best removal efficiency is recorded for the 5 bioreactors in $\mathrm{pH}$ vary from 8 to 9 for all parameters, as it has been found by Ma et al. [29] good yields have been obtained in a $\mathrm{pH}$ greater than 8 with different initial algal inoculums. This factor is considered as indicator of several biochemical activities, whose the photosynthesis and the biodegradation of the organic matter, The high $\mathrm{pH}$ values are attributed to higher photosynthetic rates of algae, [44]. Many factors can affect the $\mathrm{pH}$ of the bioreactors, such as the growth of microalgae $(\mathrm{pH}$ increase as a result of the absorption of $\mathrm{CO}_{2}$ ), nitrification of $\mathrm{NH}_{4}-\mathrm{N}$ ( $\mathrm{pH}$ decreases due to the release of $\mathrm{H}^{+}$) and excretion of acid or basic metabolite from the biodegradation of organic matter and $\mathrm{CO}_{2}$ released by respiration [45]. 


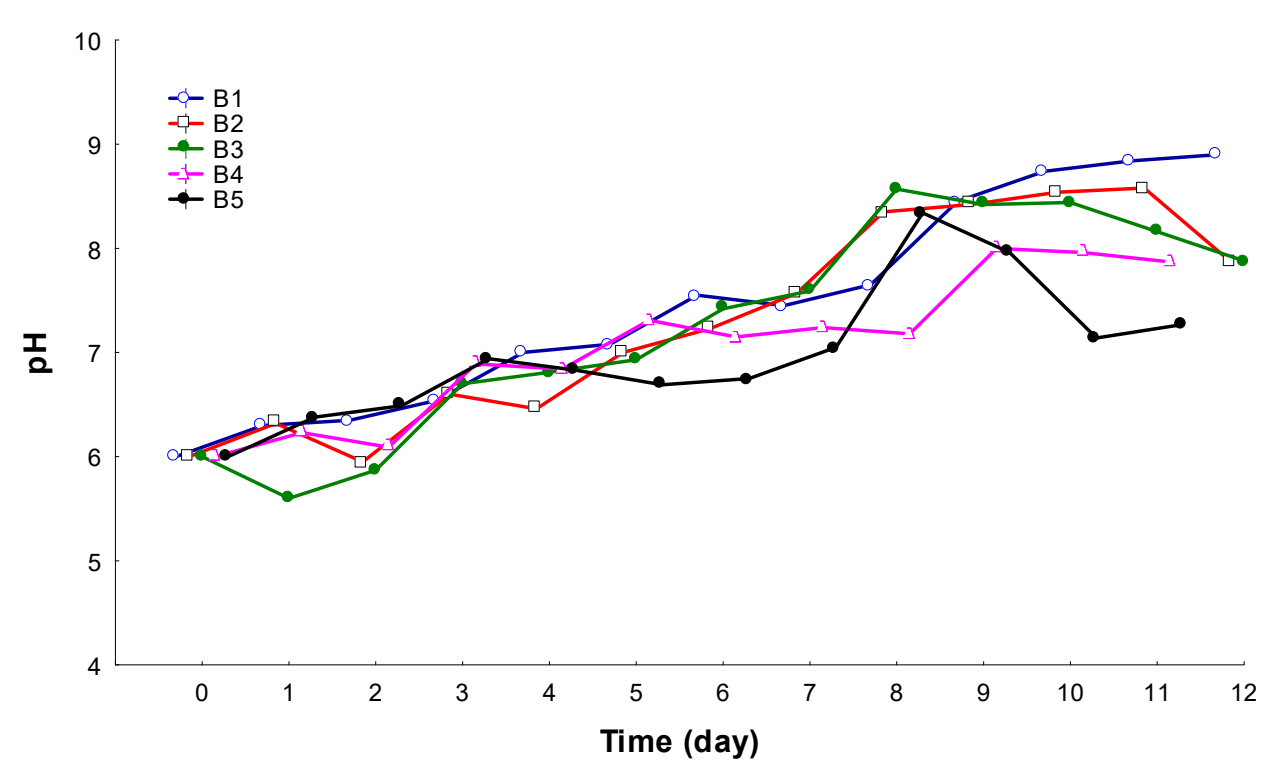

Fig.8. Evolution of the $\mathrm{pH}$ according to purifying time in the bioreactors

\section{CONCLUSION}

The results of this study shows that microalgae-bacteria system have a very important role in the treatment of wastewater especially for the removal of nutrients such as: nitrate, phosphate, ammonium and COD. The contents in Ammonium, in COD, in Nitrates and in Phosphates are higher in the first days of experimentation . They reach low values in the $12^{\text {th }}$ day. In the bioreactor 1, which contains only microalgae, we note low removal yields of the order of $60.39 \%, 82.78 \%, 44.38 \%$, and $67.90 \%$ for phosphates, ammonium, COD and nitrate respectively, compared to other bioreactors with different inoculation ratio of microalgae / activated sludge. B5 is classified as better bioreactor (16.67\% micro-algae / $83.33 \%$ activated sludge) which gives a very good efficiency of treatment, with yields very important: $76.36 \%$ of phosphates was eliminated , $87.86 \%$ of ammonium, $65.73 \%$ of COD and $94.90 \%$ of nitrates. The results obtained in this study can confirm the purifying performance of the combination of activated sludge and microalgae, for the reduction of organic matter and nutrients.

\section{ACKNOWLEDGEMENTS}

The authors would also like to thank The General Directorate of Scientific Research and 
Technological Development (DGRSDT) of Algeria and the National Research Foundation (NRF) of South Africa for funding the study through the Intergovernmental Collaboration program. Partial technical assistance and funding for consumables was provided by Ibn Khaldoun University in Tiaret Algeria and Rhodes University South Africa. The authors are thankful for this support in completion of the project. We would like to thank Dr. Taqiyeddine MOUMENE research professor at Ibn Khaldoun University, who participated to the success of this work.

\section{REFERENCES}

[1] M. Nichane et M. A. Khelil, «Changements Climatiques et Ressources en Eau en Algérie: Vulnérabilité, Impact et Stratégie d'Adaptation= Climate Changes and Water Resources in Algeria: Vulnerability, Impact and Strategy of Adaptation », Revue des BioRessources, vol. 4, no 2, p. 1-7, 2014.

[2] S. Leila et al., «Fertilization value of municipal sewage sludge for Eucalyptus camaldulensis plants », Biotechnology Reports, 2016.

[3] A. Bendida, A. E.-B. Tidjani, A. Badri, M. A. Kendouci, et M. Nabou, « Treatment of domestic wastewater from the town of Bechar by a sand filter (sand of Beni Abbes Bechar Algeria) », Energy Procedia, vol. 36, p. 825-833, 2013.

[4] N. Abdel-Raouf, A. A. Al-Homaidan, et I. B. M. Ibraheem, « Microalgae and wastewater treatment », Saudi Journal of Biological Sciences, vol. 19, nº 3, p. 257-275, 2012.

[5] K. V. Gernaey, M. C. van Loosdrecht, M. Henze, M. Lind, et S. B. Jørgensen, « Activated sludge wastewater treatment plant modelling and simulation: state of the art», Environmental Modelling \& Software, vol. 19, nº 9, p. 763-783, 2004.

[6] R. J. Craggs, W. H. Adey, B. K. Jessup, et W. J. Oswald, «A controlled stream mesocosm for tertiary treatment of sewage », Ecological Engineering, vol. 6, n ${ }^{\circ}$ 1, p. 149-169, 1996.

[7] N. Renuka, A. Sood, S. K. Ratha, R. Prasanna, et A. S. Ahluwalia, «Evaluation of microalgal consortia for treatment of primary treated sewage effluent and biomass production », Journal of applied phycology, vol. 25, n 5, p. 1529-1537, 2013.

[8] L. Wang et al., «Cultivation of green algae Chlorella sp. in different wastewaters from municipal wastewater treatment plant », Applied biochemistry and biotechnology, vol. 162, no 4, p. 1174-1186, 2010.

[9] E. D. O. Ansa, H. J. Lubberding, et H. J. Gijzen, « The effect of algal biomass on the removal of faecal coliform from domestic wastewater », Applied Water Science, vol. 2, 
$\mathrm{n}^{\mathrm{o}} 2$, p. 87-94, 2012.

[10] L. Xin, H. Hong-ying, G. Ke, et S. Ying-xue, «Effects of different nitrogen and phosphorus concentrations on the growth, nutrient uptake, and lipid accumulation of a freshwater microalga Scenedesmus sp. », Bioresource Technology, vol. 101, $\mathrm{n}^{\mathrm{o}}$ 14, $\mathrm{p}$. 5494-5500, 2010.

[11] S. Aslan et I. K. Kapdan, «Batch kinetics of nitrogen and phosphorus removal from synthetic wastewater by algae », Ecological Engineering, vol. 28, nº 1, p. 64-70, 2006.

[12] N. C. Boelee, H. Temmink, M. Janssen, C. J. N. Buisman, et R. H. Wijffels, « Nitrogen and phosphorus removal from municipal wastewater effluent using microalgal biofilms », Water research, vol. 45, $\mathrm{n}^{\mathrm{o}} 18$, p. 5925-5933, 2011.

[13] C. Wang, X. Yu, H. Lv, et J. Yang, « Nitrogen and phosphorus removal from municipal wastewater by the green alga Chlorella sp. », Journal of Environmental Biology, vol. 34, $\mathrm{n}^{\mathrm{o}} 2$ suppl, p. 421, 2013.

[14] I. Woertz, A. Feffer, T. Lundquist, et Y. Nelson, «Algae grown on dairy and municipal wastewater for simultaneous nutrient removal and lipid production for biofuel feedstock », Journal of Environmental Engineering, vol. 135, nº 11, p. 1115-1122, 2009.

[15] I. Woertz, L. Fulton, et T. Lundquist, « Nutrient Removal \& Greenhouse Gas Abatement with CO2 Supplemented Algal High Rate Ponds», Proceedings of the Water Environment Federation, vol. 2009, nº 10, p. 5469-5481, 2009.

[16] J.-Y. An, S.-J. Sim, J. S. Lee, et B. W. Kim, « Hydrocarbon production from secondarily treated piggery wastewater by the green alga Botryococcus braunii », Journal of Applied Phycology, vol. 15, n 2-3, p. 185-191, 2003.

[17] L. E. De-Bashan, J.-P. Hernandez, T. Morey, et Y. Bashan, «Microalgae growth-promoting bacteria as "helpers" for microalgae: a novel approach for removing ammonium and phosphorus from municipal wastewater », Water Research, vol. 38, $\mathrm{n}^{\circ} 2$, p. $466-474,2004$.

[18] W. Mulbry, P. Kangas, et S. Kondrad, « Toward scrubbing the bay: Nutrient removal using small algal turf scrubbers on Chesapeake Bay tributaries », Ecological Engineering, vol. 36, $\mathrm{n}^{\circ}$ 4, p. 536-541, 2010.

[19] C. Zamalloa, N. Boon, et W. Verstraete, « Decentralized two-stage sewage treatment by chemical-biological flocculation combined with microalgae biofilm for nutrient immobilization in a roof installed parallel plate reactor », Bioresource technology, vol. 130, p. 152-160, 2013.

[20] I. Priyadarshani, D. Sahu, et B. Rath, « Microalgal bioremediation: current practices and perspectives », Journal of Biochemical Technology, vol. 3, nº 3, p. 299-304, 2011. 
[21] C. M. Monteiro, P. M. Castro, et F. X. Malcata, «Metal uptake by microalgae: Underlying mechanisms and practical applications », Biotechnology progress, vol. 28, $\mathrm{n}^{\mathrm{o}}$ 2, p. 299-311, 2012.

[22] C. B. Sekomo, D. P. Rousseau, S. A. Saleh, et P. N. Lens, «Heavy metal removal in duckweed and algae ponds as a polishing step for textile wastewater treatment ", Ecological Engineering, vol. 44, p. 102-110, 2012.

[23] M. R. Yaiche, A. Bouhanik, S. M. A. Bekkouche, A. Malek, et T. Benouaz, "Revised solar maps of Algeria based on sunshine duration ", Energy Conversion and Management, vol. 82, p. 114-123, 2014.

[24] Y. Su, A. Mennerich, et B. Urban, «Municipal wastewater treatment and biomass accumulation with a wastewater-born and settleable algal-bacterial culture », water research, vol. 45, $\mathrm{n}^{\mathrm{o}} 11$, p. 3351-3358, 2011.

[25] P. J. He, B. Mao, F. Lü, L. M. Shao, D. J. Lee, et J. S. Chang, « The combined effect of bacteria and Chlorella vulgaris on the treatment of municipal wastewaters ", Bioresource technology, vol. 146, p. 562-568, 2013.

[26] B. Guieysse et al., «Influence of the initial composition of algal-bacterial microcosms on the degradation of salicylate in a fed-batch culture », Biotechnology letters, vol. 24, $\mathrm{n}^{\mathrm{o}} 7$, p. 531-538, 2002.

[27] N. C. Boelee, H. Temmink, M. Janssen, C. J. N. Buisman, et R. H. Wijffels, « Balancing the organic load and light supply in symbiotic microalgal-bacterial biofilm reactors treating synthetic municipal wastewater », Ecological Engineering, vol. 64, p. 213-221, 2014.

[28] I. De Godos, C. González, E. Becares, P. A. García-Encina, et R. Muñoz, « Simultaneous nutrients and carbon removal during pretreated swine slurry degradation in a tubular biofilm photobioreactor », Applied microbiology and biotechnology, vol. 82, $\mathrm{n}^{\mathrm{0}} 1, \mathrm{p}$. 187-194, 2009.

[29] X. Ma et al., «Effect of wastewater-borne bacteria on algal growth and nutrients removal in wastewater-based algae cultivation system », Bioresource technology, vol. 167, p. 8-13, 2014.

[30] Z. Liang et al., «Efficiency assessment and $\mathrm{pH}$ effect in removing nitrogen and phosphorus by algae-bacteria combined system of Chlorella vulgaris and Bacillus licheniformis », Chemosphere, vol. 92, n 10, p. 1383-1389, 2013.

[31] R. Tandlich, Novel Approaches to Rainwater Harvesting and Sanitation in Developing Countries. Nova science publishers, 2017.

[32] P. M. Mambo, D. K. Westensee, B. M. Zuma, et A. K. Cowan, « The Belmont Valley 
integrated algae pond system in retrospect », Water $S A$, vol. 40, n 2, p. 385-394, 2014.

[33] H. Johnson, «Co-utilisation of Microalgae for Wastewater Treatment and the Production of Animal Feed Supplements », 2010.

[34] R. Tandlich, C. D. Luyt, et N. P. Ngqwala, «A community-based rainwater monitoring and treatment programme Grahamstown, South Africa ", Journal of Hydrocarbons, Mines, and Environmental Research, vol. 5, $\mathrm{n}^{\mathrm{0}}$ 1, p. 46-51, 2014.

[35] K. Whittington-Jones, R. Tandlich, B. M. Zuma, S. Hoossein, et M. H. Villet, «Performance of the pilot-scale mulch tower system in treatment of greywater from a low-cost housing development in the Buffalo City, South Africa », International Water Technology Journal, vol. 1, $\mathrm{n}^{\mathrm{o}}$ 2, p. 165-181, 2011.

[36] Y. Su, A. Mennerich, et B. Urban, « Synergistic cooperation between wastewater-born algae and activated sludge for wastewater treatment: influence of algae and sludge inoculation ratios », Bioresource technology, vol. 105, p. 67-73, 2012.

[37] N. P. Ngqwala, R. Tandlich, S. Al-Adawi, M. Ahmed, et P. Madikizela, «REUSE OF GREYWATER TO RETRENCH WATER NEEDS » 2015.

[38] Z. J. Mudryk, P. Perliński, J. Antonowicz, et D. Robak, « Number of bacteria decomposing organic phosphorus compounds and phosphatase activity in the sand of two marine beaches differing in the level of anthropopressure ", Marine pollution bulletin, vol. 101, $\mathrm{n}^{\mathrm{O}} 2$, p. 566-574, 2015.

[39] C.-H. Liao et R. N. Dawson, «Microbiology of two-stage Kraft waste treatment », Journal (Water Pollution Control Federation), p. 2384-2396, 1975.

[40] B. N. Uba, "Microbiological characteristics of wastewaters from a nitrogen-and phosphate-based fertilizer factory ", Bioresource technology, vol. 51, $\mathrm{n}^{\mathrm{0}} 2$, p. 143-152, 1995.

[41] G. W. Fuhs et M. Chen, «Microbiological basis of phosphate removal in the activated sludge process for the treatment of wastewater ", Microbial Ecology, vol. 2, n ${ }^{0}$ 2, p. 119-138, 1975.

[42] J. Ruiz, P. Alvarez, Z. Arbib, C. Garrido, J. Barragán, et J. A. Perales, «Effect of nitrogen and phosphorus concentration on their removal kinetic in treated urban wastewater by Chlorella vulgaris », International journal of phytoremediation, vol. 13, $\mathrm{n}^{\mathrm{o}} 9$, p. 884-896, 2011.

[43] Y. Zhang et al., «The effect of bacterial contamination on the heterotrophic cultivation of Chlorella pyrenoidosa in wastewater from the production of soybean products », Water research, vol. 46, $\mathrm{n}^{\mathrm{o}} 17$, p. 5509-5516, 2012.

[44] D. M. Mahapatra, H. N. Chanakya, et T. V. Ramachandra, «Treatment efficacy of 
algae-based sewage treatment plants », Environmental monitoring and assessment, vol. $185, n^{\circ} 9$, p. $7145-7164,2013$.

[45] C. González, J. Marciniak, S. Villaverde, C. León, P. A. García, et R. Munoz, « Efficient nutrient removal from swine manure in a tubular biofilm photo-bioreactor using algae-bacteria consortia », Water Science and Technology, vol. 58, $\mathrm{n}^{\circ}$ 1, p. 95, 2008.

\section{How to cite this article:}

Khaldi H, Maatoug M, Dube C S, Ncube M, Tandlich R, Heilmeier H and Laubscher R K. Efficiency of wastewater treatment by a mixture of sludge and microalgae. J. Fundam. Appl. Sci., 2017, 9(3), 1454-1472. 